\author{
Zolotareva Natalia \\ Ph.D. in Art History, \\ Associate Professor, Piano Department, \\ Dnipropetrovsk Conservatory named after M.Glinka \\ natalyazolo@meta.ua
}

\title{
PARAPHRASE IN THE GENRE SYSTEM OF PIANO TRANSCRIPTIONS OF FRANZ LISZT
}

Purpose of the research is to reveal the location of Paraphrase in the genre system of Franz Liszt's pianistic transcription heritage. Methodology. The research methodology is based on the principle of historicism, system approach, genre analysis, methods of intonation-dramaturgy, and structural-functional analysis. Scientific novelty. The place of Paraphrase in the system of genres of the transcriptional sphere of F. Liszt was revealed; artistic methods and principles, operating in time-space Liszt's "Rigoletto. Paraphrase de Concert" were established; the content of the Paraphrase concept in the legacy of F. Liszt is clarified. Conclusions. A review of the scientific literature has made it possible to determine the place of the Paraphrase genre in the hierarchical system of piano transcriptions as a species, along with Reminiscences which goes back to the genus Fantaisie and the type of Transcription. Paraphrases in the works of F. List appear at a later stage than the Reminiscences ("Ernani., Paraphrase de Concert" - 1849, revised in 1859, "Rigoletto, Paraphrase de Concert" - 1859). It is revealed that in the work of F. Liszt Paraphrase does not play the role of genre generalization in the system of writings of the transcriptor sphere, and Reminiscences, having reached the heyday phase, has a significant impact on the interpretation of Paraphrase, the essence of which is the transformation from salon into a concert genre. At the same time, fragments from operas remain the object of the Paraphrase replay, and the method of recomposition is retelling of fragments of operatic memories. "Rigoletto is analyzed. Paraphrase de Concert" of F. Liszt allowed to reveal artistic methods and principles that operate in time-space compositions. The use of the reminiscence method is manifested in the conceptualization of the genre and philosophical interpretation of the operatic prototype. The interaction of the reminiscence method with fantasy is evidenced by the free sequence of episodes of the fragment of the quartet from the third act of the opera by G. Verdi. The process of synthesis is the interaction of genres of transcription, fantasy, reminiscences, opera, features Capriccio, which unites the style of Paraphrase. The method of symphonism is expressed in a through development, and the method of Shakespearization is in gravitation towards dra$\mathrm{ma}$, in an effort to philosophical generalization. Among the principles applied by F. Liszt there are the laws of transcendental virtuosity and concerts. The innovative interpretation of Paraphrase in the works of F. Liszt marks the beginning of a new stage in the history of the genre.

Key words: genre system, piano transcription, Fantaisie, Reminiscences, Paraphrase, composer's interpretation of the opera source.

Золотарьова Наталя Сергіївна, кандидат мистецтвознавства, доцент кафедри фрортепіано Дніпропетровської академії музики ім. М. І. Глінки

Жанр Paraphrase в системі жанрів фортепіанних транскрипцій Ференца Ліста

Мета дослідження. Дослідження спрямовано на виявлення місця Paraphrase в жанровій системі фоортепіанної транскрипторської спадщини Ф. Ліста. Методологія дослідження базується на принципі історизму, системному підході, жанровому аналізі, методах інтонаційно-драматургічного і структурно-функціонального аналізу. Наукова новизна. Виявлено місце Paraphrase в системі жанрів транскріпторской сфрери Ф. Ліста; встановлені художні методи і принципи, які діють у часі-просторі лістівської «Rigoletto. Paraphrase de Concert»; уточнено зміст поняття Paraphrase в спадщині Ф. Ліста. Огляд наукової літератури дозволив визначити місце жанру Paraphrase в ієрархічній системі фортепіанних транскрипцій як виду, поряд з Reminiscences, висхідного до роду Fantaisie і типу Transcription. Paraphrases в творчості Ф. Ліста з'являються на більш пізньому етапі, ніж Reminiscences («Ernani. Paraphrase de Concert» - 1849, переробл. 1859; «Rigoletto. Paraphrase de Concert» - 1859 р.). Виявлено, що в творчості Ф. Ліста Paraphrase не відіграє ролі жанрового узагальнення в системі творів транскрипторської сфери, a Reminiscences, досягнувши фази розквіту, здійснює значний вплив на трактування Paraphrase, сутність якого полягає в перетворенні з салонного на концертний жанр. При цьому об'єктом відтворення в Paraphrase залишаються фрагменти з опер, а методом рекомпозиції - переказ фрагментів оперних спогадів. Здійснений аналіз «Rigoletto. Paraphrase de Concer » Ф. Ліста дозволив виявити художні методи і принципи, які діють у часі-просторі твору. Застосування ремінісцентного методу проявляється в концептуалізації жанру, філософській інтерпретації оперного прообразу. Про взаємодію ремінісцентного методу з фантазійністю свідчить вільна послідовність епізодів фррагменту квартету з третьої дії опери Дж. Верді. Метод синтезу полягає у взаємодії жанрів транскрипції, франтазії, ремінісценцій, опери, ознак Capriccio, які об'єднує жанр Paraphrase. Метод симфонізму виражається в наскрізному розвитку, а метод шекспіризаціі - в тяжінні до драми, в прагненні до фрілософського узагальнення. Серед принципів, застосованих Ф. Лістом - принципи трансцендентної віртуозності і концертності. Новаторське трактування Paraphrase в творчості Ф. Ліста означає початок нового етапу в історії жанру.

Ключові слова: жанрова система, фортепіанна транскрипція, Fantaisie, Reminiscences, Paraphrase, композиторська інтерпретація оперного першоджерела.

Золотарева Наталья Сергеевна, кандидат искусствоведения, доцент кафеедры фортепиано Днепропетровской академии музыки им. М. И. Глинки

Paraphrase в системе жанровфортепианных транскрипций Ференца Листа

Цель исследования. Исследование направлено на выявление местоположения Paraphrase в жанровой системе фортепианного транскрипторского наследия Ф. Листа. Методология исследования базируется на принципе историзма, системном подходе, жанровом анализе, методах интонационно-драматургического и струк-

(c) Zolotareva N., 2018 
турно-функционального анализа. Научная новизна. Выявлено место Paraphrase в системе жанров транскрипторской сферы Ф.Листа; установлены художественные методы и принципы, действующие во временипространстве листовской «Rigoletto. Paraphrase de Concert»; уточнено содержание понятия Paraphrase в наследии Ф. Листа. Выводы. Обзор научной литературы позволил определить место жанра Paraphrase в иерархической системе фортепианных транскрипций как вида, наряду с Reminiscences, который восходит к роду Fantaisie и типу Transcription. Paraphrases в творчестве Ф. Листа появляются на более позднем этапе, чем Reminiscences («Ernani. Paraphrase de Concert» - 1849, перераб. в 1859; «Rigoletto. Paraphrase de Concert» - 1859). Выявлено, что в творчестве Ф. Листа Paraphrase не играет роль жанрового обобщения в системе сочинений транскрипторской сфреры, a Reminiscences, достигнув фазы расцвета, оказывает значительное воздействие на трактовку Рагаphrase, сущность которого заключается в превращении из салонного в концертный жанр. При этом объектом воспроизведения в Paraphrase остаются фрагменты из опер, а методом рекомпозиции - пересказ фрагментов оперных воспоминаний. Осуществленный анализ «Rigoletto. Paraphrase de Concert» Ф. Листа позволил выявить художественные методы и принципы, которые действуют во времени-пространстве сочинения. Применение реминисцентного метода проявляется в концептуализации жанра, философской интерпретации оперного прообраза. О взаимодействии реминисцентного метода с фантазийностью свидетельствует свободная последовательность эпизодов фрагмента квартета из третьего действия оперы Дж. Верди. Метод синтеза заключается во взаимодействии жанров транскрипции, фантазии, реминисценций, оперы, черт Сарriccio, объединяет которые жанр Paraphrase. Метод симфонизма выражается в сквозном развитии, а метод шекспиризации - в тяготении к драме, в стремлении к философскому обобщению. Среди принципов, примененных Ф. Листом - принципы трансцендентной виртуозности и концертности. Новаторская трактовка Paraphrase в творчестве Ф. Листа означает начало нового этапа в истории жанра..

Ключевые слова: жанровая система, фортепианная транскрипция, Fantaisie, Reminiscences, Paraphrase, композиторская интерпретация оперного первоисточника.

Relevance of the research. Ambiguity, which takes place in the scientific literature in connection with the genre differentiation of transcriptions, is provoked by the historical and artistic situation characteristic of the era of their emergence in the works of F. Liszt. Most Transcriptions were written by the composer during the concert period, in connection with which the creative freedom inherent in these works provided the appearance of liberty to publishers, journalists and critics, who allowed themselves freely to determine the author's genre name of works of this type, calling them Fantaisie, then Reminiscences, then Paraphrase. Theoretical propositions concerning the development of principles for the classification of transcriptions are projected in this study on the works of F. Liszt to elucidate the specific role of Paraphrase in the system of genres of the transcriptor sphere of the composer.

Among Liszt's pianistic transcriptions, the notoriously studied area is the compositions designated by the composer as Paraphrase, which was provoked by a different interpretation of their genre interpretation. The relevance of the study is due to the need to establish a unified scientific approach to the genre interpretation of Paraphrase as an artistic phenomenon.

The purpose of the research is to reveal the place of Paraphrase in the genre system of F. Liszt's pianistic transcription heritage.

The scientific novelty of the study lies in the fact that the place of Paraphrase in the genre system of the transcriptional sphere of F. Liszt was revealed for the first time; artistic methods and principles, operating in time-space sheet "Rigoletto. Paraphrase de Concert " were established; the content of the Paraphrase concept in the legacy of $\mathrm{F}$. Liszt was clarified.

Statement of basic materials. A significant problem in musicology, designated by $\mathrm{N}$. Ivanci, is the same interpretation of "genetically related musical phenomena" [5, 7], which form a circle of transcriptions. G. Colton reveals the content of the problematic situation around Transcription, Arrangement, Reminiscences, Paraphrase, Fantaisie in the thesis "The Art of Piano Transcription in Critical Comments" [16]. Tracing the history of the development of transcription from the XIV and up to the end of the XX century, the researcher emphasizes that the genre he studies "reaches its climax in the XIX century" [16, 3]. G. Colton proposes to divide transcriptions into two classes. In his opinion, the first class is formed by the so-called "precise" transcriptions - simplified versions of the original for amateur, home-made music. The second class is the transcriptions used by concert pianists to demonstrate virtuosity. According to G. Colton's classification, the leafy Fantaisie, Reminiscences, Paraphrase should be attributed to the second class, as they were created for performance on the concert stage, including, for the demonstration of virtuosity. G. Colton as a demarcation proposed "transcription line" [16,9], at one pole of which there are accurate transcriptions, on the other - paraphrases.

It is significant to divide the works created by creations of other authors, presented by N. RimskyKorsakov to solve the problem situation inherent in this research $[12,230]$. Therefore, easy arrangements for amateur pianists, he means de facile, more complex compositions get de salon definition and, finally, virtuosic transcriptions - de concert. Taking into account the position of N. Rimsky-Korsakov, Paraphrase F. Liszt should be attributed to transcriptions de concert.

Differentiating the content of the terms "transcription" and "arrangement," scientists demonstrate the lack of a unified approach to the definition of these genre definitions. Thus, S. Davis, for example, believes that "transcription should achieve greater fidelity to the original than the arrangement" [17, 218], and according to E. Howard-Jones, "Arrangement is a play on notes on another instrument, and transcription is a recre- 
ation of $\langle\ldots\rangle$ with reliance on imagination and creative content" [18, 305]. In the studies of G. Colton and E. Howard-Jones, transcription, unlike arranging, is associated with such concepts as "recomposition" and "recreation."

A. Dolzhansky in the definition of transcription indicates that transcription is translated from Latin rewriting (italics mine, N.Z.), and gives two interpretations of the concept: 1. "The same as the arrangement", the arrangement. 2. "Same as fantasy or paraphrase" [2, 297]. The researcher does not distinguish between transcription, arrangement, fantasy and paraphrase, not taking into account that the freer transcription, the scale of rewriting becomes less critical. As for paraphrases, the creation of the works of this genre does not imply rewriting, since this is a retelling of the episode of opera that was heard and remembered.

G. Colton emphasizes that in the XIX century "works for solo transcendent virtuosity, in which melodies, usually from operas, were reworked" were popular, for example, F. Liszt "Rigoletto. Paraphrase de Concert". Such plays could also be called Fantasia and Reminiscences and were distinct from works that were exact transcriptions" [16,7]. The researcher is inclined to define almost all free transcriptions of F. Liszt as Paraphrase. This position is discussed and cannot be unconditionally referred to an array of free virtuoso transcriptions of the romantic composer. For the composition of Paraphrase F. Liszt allowed himself to address only in 1849, when the concert period in the biography of the composer ended and the reminiscence approach to the "recompositions" of the opera prototype was formed and repeatedly tested in his work.

Developing the principles of the differentiation of transcriptions, G. Colton proceeds from the nature and scale of the transformation of "alien material," not taking into account his (that is, someone else's) properties. At the same time, it seems that it is the properties and the volume of "foreign material" that appear as the most important basis for intra-genre differentiation of transcriptions. The common property of transcriptions is the presence of "playback object" [14, 115], the scale and type of development of which changes depending on the genre orientation: in Fantaisie "object play" is the theme or themes of the opera, in the Paraphrase - a fragment of the opera works, in Reminiscences - opera whole, subjected to composer conception. The criteria for the differentiation of transcriptions are thus: 1 . the type of functioning of the object of reproduction (theme, fragment or artistic integrity); 2 . The method of his composer's re-creation (the presence or absence of composer conception).

One cannot but agree with $\mathrm{N}$. Rezheninova that modern practice is characterized by "the variability in the solution of the problem of definition in domestic and foreign dictionaries" [13, 133]. N. Rezheninova's attempt to create "a more objective picture of the definition of criteria" $[13,134]$ leads to the discovery of the most universal, in her opinion, term - "transposition" as "an auxiliary tool for the formulation of ... definitions" ... "Arrangement," "Processing", "Transcription" $[13,134]$. Transcription, in the opinion of the researcher, has "an independent artistic significance," although, like the arrangement, is a transposition of a musical composition.

Thus, if we compare the classification of $\mathrm{G}$. Colton and the conclusions of N. Rezheninova, the following differences become apparent. The first class of transcriptions according to G. Colton - exact transcriptions, according to N. Rezheninova - arrangements; second class in the work of the American scientist are free transcriptions, "recomposition," which corresponds to the work of N. Rezheninova interpretation of transcriptions as "creative processing," which from the nineteenth century became an independent concert genre that concerns Fantaisie and Paraphrase, then considering them related terms, N. Rezhininova based on the definition of the "Encyclopedic Music Dictionary" edited by B.S. Shteynpressa and I.M. Yampolsky, would, in her view, to differentiate these two concepts: "Paraphrase $\langle\ldots\rangle$ is similar in type to free fantasy, but differs from it by a simpler construction" $[13,380]$. That is, only the simplicity or complexity of construction is the criterion for the differentiation of paraphrases and fantasies. At the same time, the researcher emphasizes that this concerns the structure, the formation, but not the level of the "degree of transformation of the source" $[13,134]$. Important, in our opinion, is N. Rezheninova's conclusion about the "principle of variation in the existence of original works" $[13,135]$, which is why the problems of creating a terminology base arise. After all, Paraphrase, Fantaisie, and Reminiscences have a common "external structure," at the same time their "internal structure" is different. Based on the same phenomenon - the opera, Paraphrase is a "story about him," and Fantaisie and Reminiscences express "his attitude towards him" [1, 17]. Paraphrase refers to the epic since it is an action given through a story; opera-action as a show-belongs to the theater, and Reminiscences and Fantaisie as genres related to the expression of the author's attitude to this action belong to the sphere of lyrics (according to M. Aranovsky $[1,19]$ ).

Relying on the provisions of the above-mentioned studies, as well as the work of A. Zharkov [3], N. Prokina [11], I. Timchenko-Byhun [15], it seems expedient to develop an original interpretation of the paraphrase genre, based on its location in the system of products of the transcriptor sphere in F. Liszt's piano art.

In the "Music Encyclopedia" paraphrase (from the Greek - retelling) is interpreted as "widespread in the nineteenth-century designation of virtuosic instrumental fantasies, mainly for pianoforte, on topics of popular songs, opera arias, etc. These themes are often subjected to a significant transformation in Paraphrases, appear in new relationships with each other. Most of the Paraphrase belongs to salon music" [10, 178]. Given this definition, the same interpretation of Paraphrase and Fantaisie can hardly be justified. But important here is the recognition that "some artistically significant Paraphrases were created by Liszt" [10, 
178]. At the same time next to "Rigoletto. Oper von Verdi Konzert-Paraphrase" indicates "Polonaise" from the opera by PI Tchaikovsky "Eugene Onegin," not designated by the composer as Paraphrase.

J. Milstein, who developed the differentiation of F. Liszt's transcriptions and gave definitions of Fantasy, Reminiscences, Paraphrase, Illustration, Processing and Score, believes that in F. Liszt's work "paraphrase means a work consisting of a developed retelling of a musical theme borrowed from someone else's work (mostly <...> from the opera)» [6, 297]. If Paraphrase (according to J. Milstein) is a "retelling of a musical theme," then Reminiscences - memories of opera as integrity, in Fantaisie transcription subject (themes) from the opera. Therefore, Paraphrase, Fantaisie and Reminiscences differ among themselves by the creative method of their recomposition.

According to the concept of E. Nazaykinsky [8], musical genres are divided into "types, classes, general and types of musical works" [8,94]. From this point of view, the compositions of F. Liszt's transcriptional sphere can be divided as follows: Fantasie represents genus, the type is Transcription, and the species is Reminiscences and Paraphrase, which involves the synthesis of genres of transcription, fantasy, and reminiscences in time-space of retelling memories of fragments of opera compositions. Reliance on the provisions of the classification of the genre theory of the researcher allowed us to establish that in the genre system Transcription - Fantasie - Reminiscences - Paraphrase in the works of F. List the Transcription genre assumes the leading role, although in the composer Paraphrase as "the author's genre name is absent, acting on the level of principle" 4,5].

In the legacy of F. Liszt there are found two concert paraphrases of fragments of Verdi's operas "Ernani" and "Rigoletto." Among the undiscovered works in the regular list of Liszt works, J. Milstein points out "Paraphrase on the fourth act of Don Sebastian" by Kullak [7, 418]. In his opinion, the works designated F. Liszt as "paraphrases on opera themes," the composer's work was no more. However, contrary to this statement of the researcher, for example, in the edition "Edition Peters" the leaf version of "Miserere" from the opera "Troubadour" is designated as "Troubadour-Paraphrase."

To the definitions of free, virtuosic transcriptions, given by G. Colton, E. Howard-Jones as concert compositions based on "recomposition," in connection with F. Liszt's work, the quality of transcendental virtuosity should be added. The presence of this quality makes it possible to define Paraphrase as transcendental virtuoso transcriptions. In this case, Paraphrase is a genre variety of free, obscure, virtuoso transcriptions in the style of de concert, in which the retelling of a fragment of the whole opera is subjected to compositional interpretation in the newly created artistic integrity.

The analysis of "Rigoletto. Paraphrase de Concert "(1859) F. Liszt made it possible to reveal that the fragment of the quartet from the third act of G. Verdi's opera Rigoletto (48-100 bar-lines) was the basis for the creation of the romantic composer. ${ }^{1}$ What influenced the election of the composer as the basis of Paraphrase this particular episode of the opera? In the opera genre, the ensemble, according to G. Ordzhonikidze, as a "specifically musical form" makes it possible to feel "the organic interconnection of various aspects of the drama, diversity in unity" $[9,27]$. The musical ensemble, in this case the quartet, enabled F. Liszt to reveal irreconcilable contradictions, the struggle of strong characters, to expose the features of the images of the Duke, Maddalena, Gilda, Rigoletto due to the plasticity of the texture, the through development of the intoneme, using the creative method of Shakespiration, inherent in the thinking of the romantic composer.

The third act in the opera opens the Prelude, the scene and Duke's song "The Heart of the Beauties" (No. 15). Paraphrase F. Liszt also precedes Preludio, but the tonality (a-moll-E-dur), tempo (Adagio-Allegro), dynamics (pp-poco f), musical material are changed. Preludio compares two images from the quartet (No. 16) - the laughter of Maddalena and the suffering of Gilda. The two conducting of this contrasting musical material are divided timbrally (the laughter of Maddalena in the low, and the tears of Gilda in the high registers of the piano), the fermats, and if the first is designated a capriccio, poco $f$, then the second assumes a dynamic decline - mf with more accelerated movement - poco accelerando.

The third exercise is, as it were, the "splinters" of the Maddalena theme on $p$, interrupted by chords of staccato, where the theme of Rigoletto's revenge is guessed. A small expansion leads to the initial tempo and arpeggiated passages of poco Veloce, accelerando first in contrast dynamics (f-pp), and then the amplification of the dynamics suddenly breaks $\mathrm{pp}$ on the chromaticized quartol movement in the right and the triplets in the left hand in the high piano register. Due to the mentioned issue F. Liszt modulates into the tonality of the operatic source Des-dur (meaning the fragment of the quartet of Duke, Maddalena, Gilda, and Rigoletto, whose beginning is marked by the song of Duke "Oh, the Beauty of the Young" - 48-49 bar-lines). The Maddalena in a high register finishes the Preludio on pp theme, unlike the initial bars that sound in the bass key. Thus in Preludio, there is a sketch of the conflict, the personification of the images of Maddalena and Gilda, a contrasting juxtaposition of the idea of laughter and suffering.

F. Liszt for the first section (A) Paraphrase chose the stage of seduction - the second phase of the quartet from the third act of the opera by G. Verdi (48-49-63 bar-lines), where there is almost complete coincidence with the operatic source in terms of structure (16), tonality (Des-dur), tempo (Andante), register of the solo voice (tenor) in Duke's song "Oh, beautiful young woman".

The second section (B) returns the "dialogue" of the themes of the Maddalena and Gilda, but if the theme of suffering sounds in a high register corresponding to the soprano of the heroine, then the laughter of Maddalena (pp) is transcribed by Liszt from the orchestra party. In this section, there is a transformation of 
64-71 quartet bar-lines, where the theme of laughter of Maddalena receives the most significant development, and Gilda's party is submitted precisely, except a certain change in the rhythmic structure of 69 and 71 bar-lines. Further F. Liszt sempre piu appassionato e crescendo modifies the theme of Maddalena, isolating a separate chant from her, which as a result of transformations turns into an intonim of the theme of Gilda's suffering. The second section completes the cadence, which performs the function of the watershed between the second and third sections of Paraphrase.

In the third section of Paraphrase (A1), the synthesis of the themes of Duke and Maddalena occurs, F. Liszt transcribes 74-81 quartet bar-lines. It would seem that the transcript follows Verdi's text, except the pass 72-73 bar-lines precisely, and setting forth Duke's song "Oh, the Beauty" somewhat changes the rhythmic structure. With 78 bar-lines of the quartet in Paraphrase, Maddalena's laughter is replaced by virtuoso passages sempre legato, pp sempre cord, and from 80 bar-lines is subjected to four transformations.

Cadentious construction leads to a repeat of the sheet variant 74-81 quartet bar-lines from the opera "Rigoletto" by G. Verdi. But the front of the 81 quartet bar-lines in F. Liszt's version precedes the development of the Duke's theme, and not the Maddalena, as was the case in the first version. The next farm marks the beginning of a three-stroke episode that fulfills the role of completing the third section.

Excluding 82 bar-lines of a quartet from the opera, F. Liszt then begins to transcribe 83-100 bar-lines from the original source of G. Verdi. The final, fourth section of Paraphrase is a "dialogue" between Gilda and Rigoletto, although the latter's part appears in the piano composition only from the fifth bar of this section. F. Liszt twice presents 83 and 84 quartet bar-lines, where dolce, con somma passionate the theme of Gilda's suffering "Heart is poor, be brave" sounds. Rigoletto's theme in Paraphrase is set out first by the sixteenth, then reinforced with arpeggiated octave passages rfz assai, marcatissimo.

Starting with 89 bar-lines, the sheet version of the J. Verdi quartet shows only the sufferings of Gilda $\mathrm{p}$, dolce, in the high piano register, with the octave support of the thirty-second in the right and orchestral line in the left hand. Gradually there is a dynamic injection and 95-96 bar-lines. F. Liszt, where the "dialogue" of Gilda and Rigoletto again arises, is the dramatic culmination of the section rfz assai, marcatissimo, fff.

Further, in 97-100 bar-lines. The themes of Gilda and Rigoletto, surrounded by chromatic passages, sound in the first (Gilda) and small (Rigoletto) octaves marcato ed espressivo. Two dynamic waves lead to the final episode, wherein two measures F. Liszt returns the echoes of the Duke and Maddalena, sounding dolce una corda and pp respectively. The last step of the section is "dedicated" to Gilda. Fermata separates the fourth section from the codes.

The code (Presto) is a philosophical generalization of the operatic prototype in F. Liszt's conception, which he outlined in the genre Konzert-Paraphrase.

Conclusions. Reliance on the provisions of the classification of the genre theory E. Nazaikinsky [8] allowed to establish a hierarchical system of relations between Fantasie, Transcription, Reminiscences and Paraphrase, and also to determine the place of Paraphrase in this system as a species, along with Reminiscences, which goes back to the genus Fantasie and the type of Transcription. Paraphrases in the works of $F$. Liszt appear at a later stage than Reminiscences ("Ernani., Paraphrase de Concert" - not later than 1849, revised in 1859, "Rigoletto, Paraphrase de Concert" - 1859). However, Paraphrase in F. Liszt's works does not play the role of genre generalization in the system of writings of the transcriptor sphere. On the contrary, Reminiscences, having reached the heyday, has a significant impact on the interpretation of Paraphrase, the essence of which is the transformation from salon into a concert genre. In this case, the opera fragments remain the object of reproduction in Paraphrase, and the method of recomposition is a retelling of pieces of operatic memories.

Analysis of "Rigoletto. Paraphrase de Concert "of F. Liszt allowed to reveal artistic methods and principles that operate in time-space compositions. The use of the reminiscence method is manifested in the conceptualization of the genre and philosophical interpretation of the operatic prototype. The interaction of the reminiscence method with fantasy is evidenced by the free sequence of episodes of the fragment of the quartet from the third act of the opera by G. Verdi. The method of synthesis is the interaction of genres of transcription, fantasy, reminiscences and opera, which unites the genre of Paraphrase. An important role in Paraphrase is taken by the composer Capriccio's remark, which makes it possible to see the genre features of Capriccio in the composition. The method of symphonism is expressed in a through development, and the method of Shakespearization is in gravitation towards drama, to philosophical generalization. Creating "Rigoletto. Paraphrase de Concert" F. Liszt applied the principles of transcendent virtuosity and concerts. Innovative treatment of Paraphrase in the works of F. Liszt means the beginning of a new history of the genre, the genre of Paraphrase of a new historical and artistic formation.

\section{Notes}

${ }^{1}$ The analysis is carried out on the key of the opera by G. Verdi "Rigoletto." (1977). p. 296. Edition of Lizst Zwei Paraphrasen "Rigoletto Oper von Verdi. Konzert-Paraphrase." Leipzig: C. F.Peters. 2-12. 


\section{תimepamypa}

1. Арановский М. Структура музыкального жанра и современная ситуация в музыке // Музыкальный современник : [сб. статей / редкол.: В. В. Задерацкий, В. И. Зак, С. С. Зив (сост.)]. М. : Сов. композитор, 1987. Вып. 6. С. 5-44.

2. Должанский А. Н. Краткий музыкальный словарь. СПб. : Лань : Планета Музыки, 2007. 448 с. : ил.

3. Жарков А. Н. Художественный перевод в музыке: проблемы и решения : дис. ... канд. искусствоведения : спец. 17.00.03 - Музыкальное искусство. К., 1994. 180 с.

4. Золотарьова Н. С. Reminiscences Ф. Ліста: теорія жанра : автореф. дис. ... канд. мистецтвознавства : спец. 17.00.03 - Музичне мистецтво; Харк. нац. ун-т мистецтв імені І. П. Котляревського. Х., 2013.17 с.

5. Иванчей Н. П. Фортепианная транскрипция в русской музыкальной культуре XIX века : автореф. дис. ... канд. искусствоведения : спец. 17.00 .02 - Музыкальное искусство; Ростовская гос. конс. (академия) им. С. В. Рахманинова. Ростов н/Д., 2009. 32 с.

6. Мильштейн Я. Ф. Лист. В 2 т. Т. 1. Изд. 2-е расш. и доп. М. : Музыка, 1971. 864 с.

7. Мильштейн Я. Ф. Лист. В 2 т. Т.2. Изд.2-е расш. и доп. М. : Музыка, 1971. 600 с.

8. Назайкинский Е. В. Стиль и жанр в музыке : учеб. Пособие. М. : Владос, 2003. 248 с.

9. Орджоникидзе Г. Оперы Верди на сюжеты Шекспира. М. : Музыка, 1967. 327 с.

10. Римский-Корсаков Н. А. Летопись моей музыкальной жизни / Н. А. Римский-Корсаков. 8-е изд. М. : Музыка, 1980. 453 с.

11. Парафраза // Муз. энциклопедия : [в 6 т.] / гл. ред. Ю. В. Келдыш. М., 1978. Т. 4. - СТб. 178.

12. Прокина Н. В. Фортепианная транскрипция. Проблемы теории и истории жанра : автореф. дис. ... канд. искусствоведения : спец. 17.00.02 - Музыкальное искусство; Моск. гос. конс. им. П. И. Чайковского. М., 1988. $21 \mathrm{c}$.

13. Реженинова Н. Р. Понятие «Фортепианное переложение» как терминологическая проблема ) // Общество. Среда. Развитие (Terra Humana). 2012. № 3. -URL: http://cyberleninka.ru/article/n/ponyatie-fortepiannoeperelozhenie-kak-terminologicheskaya-problema.

14. Рощенко Е. Г. Историко-социальные функционирования музыкально-культурного наследия в композиторском творчестве : дис. ... канд. искусствоведения : спец. 17.00.02 - Музыкальное искусство. К., 1988.196 с.

15. Тимченко-БихунІ. Фортепіанні парафрази М.І. Глінки: стильові процеси в контексті міжнаціональних взаємодій : автореф. дис. ... канд. мистецтвознав. : спец. 17.00.01 / І. Тимченко-Бихун ; Нац. муз. акад. України ім. П. І.Чайковського. К., 2008. 17 с.

16. Colton G. D. The Art of Piano Transcription as Critical Commentary. McMaster University, Hamilton, Ontario, $1992.63 \mathrm{p}$.

17. Davies S. Transcription, Authenticity and Performance // British Journal of Aesthetics. — 1988. № 28/3 (Summer). P. 216-227. P. $305-311$.

18. Howard-Jones E. Arrangements and Transcriptions // Music and Letters. 1935. Vol. 16, № 4 (october).

\section{References}

1. Aranovskiy, M. (1987). The structure of the music genre and the modern situation in music, Muzykal'nyy sovremennik, 6, 5-44. [in Russian].

2. Dolzhanskiy, A. N. (2007). Short musical dictionary. SPb. : Lan' : Planeta Muzyki [in Russian].

3. Zharkov, A. N. (1994). Art translation in music: problems and solutions. Ph.D's thesis. Kyiv [in Russian].

4. Zolotareva, N. S. (2003). Reminiscences of F. Liszt: theory of genre. Extended abstract of candidate's thesis. Kharkiv : I. P. Kotlyarevsky KhNUA. [in Ukrainian].

5. Ivanchey, N. P. (2009). Piano transcription in the Russian musical culture of the XIX century. Extended abstract of candidate's thesis. Rostov-on-Don : RSC Rachmaninov [in Russian].

6. Mil'shteyn, Y. A. (1971). F. List. In 2 vols. Vol. 1. Moscow: Muzyka [in Russian].

7. Mil'shteyn, Y. A. (1971). F. List. In 2 vols. Vol. 2. Moscow: Muzyka [in Russian].

8. Nazaykinskiy, Y. V. (2003). Style and genre in music. Moscow : Vlados [in Russian].

9. Ordzhonikidze, G. (1967). Verdi's operas on Shakespeare's stories. Moscow: Muzyka [in Russian].

10. Rimskiy-Korsakov, N. A. (1980). Chronicle of my musical life. Moscow: Muzyka [in Russian].

11. Parafraza. Music Encyclopedia. In 6 vols. Vol. 4. (1978). Moscow [in Russian].

12. Prokina, N. V. (1988). Piano transcription. The problems of theory and history of the genre. Extended abstract of candidate's thesis. MGK (univ.) im. P.I.Tchaikovsky [in Russian].

13. Rezheninova, N. R. (2012). The concept of "Piano Transposition" as a terminological problem. Retrieved from: http://cyberleninka.ru/article/n/ponyatie-fortepiannoe-perelozhenie-kak-terminologicheskaya-problema. [in Russian].

14. Roshchenko, Y. G. (1988). Historical and social functioning of the musical and cultural heritage in the composer's work. Extended abstract of candidate's thesis. Kyiv : Kiev. gos. kons. im. P. I. Chajkovskogo [in Russian].

15. Tymchenko-Bikhun, I. (2008). Piano paraphrases M.I. Glinki: stylistic processes in the context of interethnic interactions. Extended abstract of candidate's thesis. Kyiv : NMAU im. P.I. Chajkovskogo [in Ukrainian].

16. Colton G. D. (1992) The Art of Piano Transcription as Critical Commentary. (p. 163) McMaster University, Hamilton, Ontario [in English].

17. Davies S. (1988) Transcription, Authenticity and Performance. British Journal of Aesthetics, 28/3 (Summer), 216-227 [in English]. 311 [in English].

18. Howard-Jones, E. (1935) Arrangements and Transcriptions. Music and Letters, Vol. 16, 4 (october), 305- 